\title{
forests
}

ISSN 1999-4907

www.mdpi.com/journal/forests

Review

\section{Reviewing the Science and Implementation of Climate Change Adaptation Measures in European Forestry}

\author{
Marja Kolström ${ }^{1, *}$, Marcus Lindner ${ }^{1}$, Terhi Vilén ${ }^{1}$, Michael Maroschek ${ }^{2}$, Rupert Seidl ${ }^{2}$, \\ Manfred J. Lexer ${ }^{2}$, Sigrid Netherer ${ }^{3}$, Antoine Kremer ${ }^{4}$, Sylvain Delzon ${ }^{4}$, Anna Barbati ${ }^{5}$, \\ Marco Marchetti ${ }^{6}$ and Piermaria Corona ${ }^{5}$
}

1 European Forest Institute (EFI), Torikatu 34, Joensuu 80100, Finland;

E-Mails: marcus.lindner@efi.int (M.L.); terhi.vilen@efi.int (T.V.)

2 Department of Forest and Soil Sciences, Institute of Silviculture, University of Natural Resources and Life Sciences (BOKU), Peter Jordan Straße 82, Vienna A-1190, Austria;

E-Mails: michael.maroschek@boku.ac.at (M.M.); rupert.seidl@boku.ac.at (R.S.);

mj.lexer@boku.ac.at (M.J.L.)

3 Institute of Forest Entomology, Forest Pathology and Forest Protection, University of Natural Resources and Life Sciences (BOKU), Hasenauerstraße 38, Vienna A-1190, Austria;

E-Mail: sigrid.netherer@boku.ac.at

4 INRA, University of Bordeaux, UMR BIOGECO, 69 Route d'Arcachon, CESTAS Cedex 33612, France; E-Mails: antoine.kremer@pierroton.inra.fr (A.K.); sylvain.delzon@u-bordeaux1.fr (S.D.)

5 Department for Innovation in Biological, Agro-Food and Forest Systems (DIBAF), University of Tuscia, Via S. Camillo de Lellis, Viterbo 01100, Italy; E-Mails: annabarbati@tiscali.it (A.B.); piermaria.corona@unitus.it (P.C.)

6 Italian Academy of Forest Sciences, Piazza Edison 11, Florence 50133, Italy;

E-Mail: marchettimarco@unimol.it

* Author to whom correspondence should be addressed; E-Mail: marja.kolstrom@efi.int;

Tel.: +358-10-773-4334; Fax: +358-10-773-4377.

Received: 5 July 2011; in revised form: 29 August 2011 / Accepted: 3 November 2011 /

Published: 11 November 2011

Abstract: Developing adaptation measures in forestry is an urgent task because the forests regenerated today will have to cope with climate conditions that may drastically change during the life of the trees in the stand. This paper presents a comprehensive review of potential adaptation options in forestry in Europe based on three pillars: a review of the scientific literature, an analysis of current national response strategies, and an expert 
assessment based on a database compiled in the COST Action ECHOES (Expected Climate Change and Options for European Silviculture). The adaptation measures include responses to both risks and opportunities created by climate change and address all stages of forestry operations. Measures targeted to reduce vulnerability to climate change may either aim to reduce forest sensitivity to adverse climate change impacts or increase adaptive capacity to cope with the changing environmental conditions. Adaptation measures mitigating drought and fire risk such as selection of more drought resistant species and genotypes are crucial. For adaptation to be successful it is of the utmost importance to disseminate the knowledge of suitable adaptation measures to all decision makers from the practice to the policy level. The analysis of the ECHOES database demonstrates that this challenge is well recognized in many European countries. Uncertainty about the full extent of climate change impacts and the suitability of adaptation measures creates a need for monitoring and further research. A better understanding of how to increase adaptive capacity is also needed, as well as regional vulnerability assessments which are crucial for targeting planned adaptation measures.

Keywords: forestry; Europe; climate change; adaptation strategies; forest management

\section{Introduction}

Forest ecosystems play an important role in the global biogeochemical cycles. Forests act as both sources and sinks of greenhouse gases, and in doing so they have significant influence on the climate of the earth [1,2]. At the same time, forests are particularly sensitive to climate change, because the long life-span of trees does not allow for rapid adaptation to environmental changes. The currently observed rate of increase in atmospheric greenhouse gas content has exceeded earlier projections [3], and most recent studies suggest that changes caused by the current and projected further increases might to a large extent be irreversible [4]. Consequently, adaptation to climate change is now perceived as a prime challenge for modern society [5-7]. It is particularly urgent to develop adaptation strategies in forestry because the trees regenerated in forest stands today will have to cope with climate conditions that are projected to change drastically throughout their lifetime.

Global mean annual temperatures are projected to increase between 2 and 5 degrees by the year 2100 [3]. Future water availability is difficult to predict as projected precipitation changes vary regionally and shifts in the seasonal distribution of precipitation might lead to both extended dry and wet periods. The impact of climate change will include increased growth rates especially in northern Europe (at least in the short to medium term), whereas increased drought stress and aggravated biotic and abiotic disturbance regimes are expected to negatively affect forest productivity in other parts of Europe [8]. These changes will not only affect tree growth, but they will also affect mortality and competitive relations between species.

Adaptation has been defined as an adjustment in natural or human systems which moderates harmful effects or exploits beneficial opportunities in response to actual or expected climatic stimuli or their effects [9]. Adaptation strategies should include an analysis of climate vulnerability, an 
assessment of existing coping strategies, and suggestions on how management might be modified to respond to climate change [10]. Reducing vulnerability involves a reduction of sensitivity as well as an increase in adaptive capacity of forest ecosystems. The understanding of adaptive capacity in the forest sector is just evolving and is thus difficult to quantify [8]. Some changes in climate may be too fast for autonomous adaptation of forest ecosystems, and extreme events could act as tipping points threatening forests and the services and functions they provide [11]. Climate change impacts like drought induced dieback and increased disturbance related damages are already becoming increasingly evident in several regions [12-14]. On the other hand, due to its gradual progression, and complicated by huge inter-annual variability, it is challenging for decision makers to monitor climate change trends and consequences for the forests under their stewardship. Hence, decisions must inevitably be made in the face of great uncertainty. Related to forestry, two different fields of adaptation measures can be distinguished: (i) management of trees, stands, and combinations of stands in the landscape, affecting forest functions and services at the biophysical level; and (ii) activities influencing the socio-economic and political frame of sustainable forest management (SFM) and its objectives.

Climate change adaptation strategies targeted for the forestry sector have been explored in several studies for Canadian forestry [15-19]. In Europe, both model-based case studies [20-22] and theoretical reviews, have addressed the topic [23-25]. European forestry is diverse both in terms of forest types and socio-economic conditions. The ownership structure and related interests of owners and stakeholders do not allow for one-size-fits-all solutions. Regional differences in actual and projected climate change impacts are of particular importance and there are significant differences in socio-economic conditions within the forest sector [8,26].

The need to encourage adaptation to the effects of climate change in European forestry is one of three climate change related key actions in the European Union (EU) Forest Action Plan [27]. The plan calls for targeted research, training and studies on the impacts of an adaptation to climate change. In response to this call, the objective of the present study was to review the available state of knowledge on adaptation measures to changing climate in forest management in Europe. Some countries have already developed climate change strategies or programs which include measures for the forestry sector. A specific goal of the study was to collect information about on-going and planned adaptation measures in forest management to obtain an overview of the current implementation and planned future development of adaptation measures in the EU and other European countries. The objective of this paper was to summarize adaptation options by means of a thorough review of the literature, and assess the implementation of options by analyzing the COST Action ECHOES (Expected Climate Change and Options for European Silviculture) database on adaptive measures in 19 European countries.

\section{Study Area and Methods}

The study area included the 27 Member States of the EU and additional European countries participating in ECHOES (Norway, Switzerland, Croatia, Serbia and Russia) which are classified into four bioclimatic zones corresponding to the macro-bioclimates of Europe [28]: Boreal, Temperate Oceanic, Temperate Continental, and Mediterranean. The bioclimatic classification is based on the average monthly temperature range between the most extreme months of the year which has a great influence on vegetation distribution. 
A comprehensive literature review of potential adaptation options for forestry in Europe was undertaken by searching and accessing peer-reviewed literature from the Scopus abstract and citation database [29], using the keywords "adaptation", "forest" and "climate change". Additional literature searches were made for specific forestry adaptation measures, e.g., "forest regeneration", "tending of stand", "silvicultural management", "harvesting", "management planning", "forest protection", "infrastructure" and "transportation". Furthermore, project reports and national adaptation plans were reviewed where available. A limited number of references from other geographical regions with relevance for the study area were also included in the review. The adaptation measures reviewed include responses to both risks and opportunities created by climate change, and address all stages of forestry operations. For each stage potential adaptation measures were screened and documented.

A questionnaire survey was carried out to compile information about national measures for adapting forests and forestry to climate change in the EU27 Member States in the year 2008. The survey addressed national research institutes and ministries with responsibility for forestry. A total of 978 answers to the open questions were analyzed. Answers referring to similar adaptation measures were combined, if proposed technique and motivation for the application of the measure were comparable. However, if a proposed measure, for example intensified thinning had two different targets - to reduce drought stress and to respond to increased growth rates - then it was kept in the list with both motivations as separate measures.

Within the COST Action ECHOES, the list of measures obtained from the survey was transferred to a database and country representatives were asked to complement the data with information about the location, forest type and tree species to which the measures refer, the climate change impacts addressed, as well as the anticipated effectiveness, possible trade-offs and their status of implementation (ongoing/planned/idea). Additional measures could also be added by the country representatives. By August 2011, the database included a total of 444 adaptation measures from 19 countries (16 EU countries plus Switzerland, Croatia and Russia; Table 1). The database was scrutinized in this study to assess the preparedness to climate change in different bioclimatic regions. This was done by comparing the total number of adaptation measures, as well as the number of ongoing measures between the regions.

Table 1. Number of database entries (measures listed by country respondents) by bioclimatic regions and status of the measures. Since similar measures are listed by several countries, the last column shows the number of different measures per bioclimatic region.

\begin{tabular}{|c|c|c|c|c|c|c|c|}
\hline \multirow[b]{2}{*}{ Bioclimatic region } & \multirow{2}{*}{$\begin{array}{c}\text { Number of } \\
\text { respondent countries } \\
\text { in the zone } \\
\end{array}$} & \multicolumn{5}{|c|}{ Number of entries in the database } & \multirow{2}{*}{$\begin{array}{r}\text { Number of } \\
\text { different } \\
\text { measures } \\
\end{array}$} \\
\hline & & Total & Ongoing & Planned & Idea & $\begin{array}{c}\text { No } \\
\text { status } \\
\end{array}$ & \\
\hline Boreal & 2 & 28 & 16 & 1 & 11 & & 24 \\
\hline Temperate Oceanic & 7 & 195 & 100 & 50 & 5 & 7 & 79 \\
\hline Temperate Continental & 6 & 120 & 61 & 43 & 10 & 6 & 51 \\
\hline Mediterranean & 4 & 101 & 57 & 5 & 30 & 9 & 58 \\
\hline
\end{tabular}




\section{Adaptation Options in Forestry}

\subsection{Stand Level Adaptation Options}

\subsubsection{Forest Regeneration}

Forest regeneration offers a direct and immediate opportunity to manipulate species or stand composition. A highly recommended option to secure the adaptive response of established regeneration is to raise the level of genetic diversity within the seedling population [23,30-32], either by natural or artificial means. The more diverse and larger the seedling population is, the more potential there is for populations to adapt to environmental changes. Because the genetic composition of populations needs to be shifted to cope with environmental changes, present diversity levels should be increased compared to local regeneration conditions [33].

Under natural regeneration regimes, increased genetic diversity can be achieved by benefiting successive fruiting years, thereby increasing gene flow from external male parents to different seed trees. Enrichment sowing and planting in naturally regenerated stands is another option to raise the level of diversity. Natural selection works on the gene pool (local and introduced trees) and over time a population better adapted to the changing conditions develops [34,35].

The size of the seedling population is far lower in the case of artificial than in natural regeneration, unless sowing is used. Generally, only selected certified tree seed can be used in Europe. To raise levels of genetic diversity, seedlings coming from different seed stands can be mixed at the nursery stage. In addition, local material can be supplemented with introduced material from other seed sources. Given that the fitness distribution in the population is unknown, best adapted genotypes to climate change may either originate from local sources or from external sources. This is why supplemental regeneration is suggested. Supplemental regeneration also enhances evolutionary responses to new selection pressures by increasing local diversity [36].

Several national seed transfer regulations have defined provenance regions where only local populations of European tree species are recommended for establishment, but elsewhere there are no rules preventing the use of non-local material except in natural parks or reserves. Preadapted seed transfer should be based on results of provenance tests and integrate knowledge on genetic variation among populations and predicted changes of bioclimatic envelopes. Examples of climate preadapted seed transfers were recently developed for lodgepole pine (Pinus contorta) in British Columbia, either based on response functions [37], or combining ecological and genetic data [38]. In Europe, similar approaches were used for Scots pine (P. sylvestris) by Reich and Oleksyn [39], who concluded that transfer of populations would need to be made over increasingly larger distances from the south of Europe.

Tree breeding could support the development of genetic material better adapted to future climate conditions, but current expectations are rather modest. Most breeding programs of tree species in Europe focused on improving trees for production and quality traits, whereas selection criteria related to adaptation to higher $\mathrm{CO}_{2}$, higher temperatures, or longer water stress periods have been mostly neglected, or have only been introduced during the last decade [40]. Compared to traditional methods more sophisticated approaches based on biotechnology (in vitro propagation, somatic embryogenesis, gene transfer) may significantly shorten the time required to produce new commercial varieties, once 
genes of significance for adaption have been identified [41,42]. Research efforts are being conducted to identify candidate genes related to traits that will respond to climate change: (i) bud burst [43-46]; (ii) bud set [47,48]; and (iii) drought resistance and water use efficiency [49-51]. However, the achievements obtained so far are not at the stage of introducing these genes (by crossing or other means) in commercial varieties yet. Therefore, to date the only way through which breeding activities may take into account climate change would be to raise diversity within the varieties produced by seed orchards. This can be done by supplementing seed lots harvested in seed orchards with seeds stemming from other origins or other seed orchards.

Regenerating species best adapted for current conditions may result in a higher risk of dieback in the future [24]. The promotion of specific tree species includes the risk of unanticipated losses caused by "new" plant diseases that emerge and affect particular species or species groups, such as experienced in the case of Dutch elm disease or most recently with Ash dieback [52]. On the other hand, selecting new plant material adapted to the projected future climatic conditions includes considerable risk of "prognostic error" given the high uncertainties in projections of future climate at local and regional scales. Furthermore, the stands may be adapted in a sub-optimal way to current conditions [31].

Besides adaptation options aiming at reproductive material, technical options can be applied in the regeneration phase. Planting in drought prone areas can be adapted via wider initial spacing of trees in combination with rigorous weed control to reduce competition for water resources from weeds [23]. Furthermore, a shift in planting season from spring to autumn with additional site preparation could enhance drought resistance of freshly planted trees due to improved initial rooting. Planting of container seedlings might also reduce the risk of immediate drought effects [30,53]. Furthermore stand establishment with tree species that have good sprouting potential may increase future flexibility in stand regeneration as sprouts are more drought resistant compared to seedlings. Indeed, tree sprouts generally have higher rates of survival than seedlings under water stress as they benefit from resources stored in parent plants and a more extensive root system [54].

Based on the ECHOES database, climate change is already taken into account in decisions related to regeneration of forest stands. In all bioclimatic regions, species and provenances better adapted to projected future conditions are being considered to select and species that perform well across different site conditions are favored. Also tree species diversity is widely considered. In temperate regions, natural regeneration is used for the main tree species and sometimes enrichment planting of species which are robust against climate change is used in combination with natural regeneration. At nursery stage, moist-preserving chemicals are utilized in seedling production, transport and planting in Slovakia, and in Sweden nurseries have taken measures in the selection of a more plastic genetic material. In Spain nursery culture was improved to increase survival of planting stock in plantations $[55,56]$ and the number of species planted in afforestation programs has been increased to promote diversity [57].

\subsubsection{Tending, Thinning and Harvesting}

While species choice in the regeneration phase has more long-term impact, practices taking place after stand establishment to promote target species composition, stand stability, quality, and structure as well as enhancing growth of crop trees have effects on shorter timescales. Proposed adaptation 
measures aim mainly at modifying frequency or intensity of tending and thinning activities, but may also include altering tree species composition by targeted stand tending operations.

Adaptation measures in tending and precommercial thinning should support mixed stands of well-adapted tree species, inter alia to distribute risk via diversification [23]. A recent simulation study in Austria corroborated the positive adaptation effect of such measures for a wide range of stand and site conditions [58]. In the boreal zone and in high altitudes, thinning schedules should be adapted to the increased growth rates $[59,60]$. At drought prone sites thinning improves the recovery of growth in subsequent years after dry periods $[23,61,62]$. Both experimental data (e.g., $[63,64])$ and simulation studies (e.g., [65]) support the positive effect of thinnings on traits of individual tree stability. However, since canopy openings affect stand integrity and increase surface roughness, intensified thinning might be limited by increased short-term susceptibility to abiotic and biotic damages such as windthrow (e.g., [66]) or insect infestation [67]. Improved individual tree stability increases flexibility in the stand regeneration phase, thus balancing the negative effects of increased surface roughness through higher stability in partial regeneration cuts.

To counteract negative impacts of climate change in over-mature, structurally uniform forests, standing stocks have to be reduced by adapted thinning regimes focusing on increasing and maintaining structural diversity [58]. Tending and thinning can also help to manage increasingly mal-adapted stands in a changing environment [68].

Small-scale harvesting interventions and promoting harvesting systems which support natural regeneration of suitable species were recommended to increase spatial heterogeneity and biodiversity [23]. However, small-scale cutting may induce loss of light-demanding tree species, which are often also more tolerant to water stress and high temperatures [69] because they are typically pioneer species. Yet, this might be balanced by intensifying disturbance regimes under climate change (see below). Recently, continuous cover forestry and variable retention systems have been proposed as robust strategies under climate change [70], but their overall benefits in this context remain poorly investigated [22,71].

Late stand development stages are generally vulnerable to major disturbance factors (e.g., windthrow, bark beetles, fungal diseases), and harvesting activities may increase stand susceptibility [67,72]. Adaptation should thus aim at reducing predisposing stand characteristics, e.g., via minimizing stand edges exposed to prevailing winds [73] or intense direct sun exposure.

In the Boreal region, technological development in harvesting machinery will be crucial to adapt harvesting operations to warmer winters with shortened frost periods. The wintertime increase in soil moisture and reduced periods of frozen soil may cause reduced carrying capacity of soil for timber harvesting [74].

ECHOES data show that adaptation of thinning and harvesting practices is already ongoing throughout European forestry. Many countries report on modifying thinnings to reach stand structures more robust to projected conditions and extreme events. That is done by either modifying the frequency and intensity of thinning, by promoting species mixtures and/or uneven-aged/structured stands. In the temperate region, small scale regeneration methods like gaps, irregular shelterwood systems and group selection systems are preferred to increase spatial heterogeneity in forest structures. In the boreal region, harvesting methods are already adapted to better suit wet sites. In Cyprus, the 
observed dieback of trees has lead to the felling and export of dead trees for insect outbreak control and to decrease fire risk [75].

\subsection{Adaptation Options Beyond the Stand Level}

\subsubsection{Forest Management Planning}

Forest management strategies include response options beyond the level of individual stands. In forest planning, the shortening of rotation periods can be an appropriate management response to accelerated growth in mountainous or boreal environments [58], but trade-offs with in situ carbon storage [76] and a lower nutrient budget due to increased biomass extraction should be considered. Diversification of tree species mixtures and management approaches between neighboring forest stands or within a forest landscape increases adaptive capacity, hedges risks and improves the overall resilience of forest ecosystems $[24,77,78]$. As there is uncertainty about the best timing of changing species or provenances in forest regeneration, both reactive and proactive adaptation strategies can be applied simultaneously, for instance in different forest stands of a management unit. Adaptive forest management planning [79] systematically integrates results of previous interventions to iteratively improve and accommodate change, by learning from the outcomes of applied silvicultural practices under the changing external conditions [80,81].

At the stand level, individual response strategies can be mutually exclusive. For example, preferring natural regeneration in mixed forests with long rotation cycles is incompatible with planting productive genotypes managed in short rotation cycles. Over larger geographical scales of management units and forest landscapes, however, such strategies can also be combined. In addressing the complexities of landscape-scale planning forest ecosystem models and multi-criteria decision analyses have considerable potential to support forest management under changing environmental conditions [20,26,82]. As part of decision support systems these tools can facilitate a holistic uncertainty management $[83,84]$.

Based on the ECHOES database, ongoing adaptation measures in management planning concern mainly modifying the timing of the final harvest. Generally, rotation lengths are reduced due to increased productivity or to speed up the stand replacement in vulnerable stands. However, in Pinus nigra forests in Mediterranean mountains of Spain, rotation periods are lengthened due to observed difficulties in natural regeneration and mortality due to summer drought. In temperate regions and in Spain, forest growth models and Decision Support Systems (DSS) to evaluate impacts of climate change and to identify suitable management options are already developed.

\subsubsection{Pest and Diseases and Disturbance Risk Management}

Disturbance agents are expected to gain importance under climate change. Occurrence and performance of biotic agents are in flux when environmental conditions change, and there is evidence that there will be higher probabilities of damage by insect pests and fungal diseases at higher temperatures [85-87]. The observed continental scale increases in damage from disturbances is linked to ongoing climatic changes, yet changes in forest vegetation are of equal importance in explaining recent unprecedented disturbance levels [88]. Intensive forestry practice over decades has promoted stands of non-autochthonous tree species and of high structural uniformity in many parts of 
Europe - e.g., plantations of Norway spruce (Picea abies) in central Europe-with the unintentional consequence of increasing susceptibility to disturbances. Consequently, there is a high demand for comprehensive planning systems which incorporate pest risk assessment and aim to improve forest health and stability $[89,90]$. Stands mixed with species not equally susceptible to specific pest species remain less affected than monocultures [67], because the limited food resources keep pest population levels lower. On the other hand, the selection of tolerant or resistant families and clones may also be an adequate measure to reduce the risk of damage by pests and diseases in pure stands [67]. To understand the complex reasons why different diseases and pests may become a problem, comprehensive knowledge on the susceptibility of specific forest communities to disturbance by specific pathogen or insect pest species is needed. However, such knowledge is mostly lacking at the forest management level, and is also under-represented in the scientific literature. Expert models such as for the Eurasian spruce bark beetle (Ips typographus) [91,92] help foresters to identify risks and to gain awareness of the scope of potential activity especially with regard to climate change.

Increasing temperature with decreasing summer precipitation (at least in central and southern Europe) and more intense singular precipitation events [93] may lead to increasingly dry periods and increased fire risk. Current fire prevention policies need to be adjusted to cope with longer and more severe fire seasons, increasing fire frequency, and larger areas exposed to fire risk, especially in the Mediterranean region [94]. Adaptation measures include: (i) modification of forest structure (e.g., tree spacing and density, regulation of age class structure); (ii) fuel management (prescribed burning, thinning, pruning and biomass removals, grazing), with priority given to forest types with the ability to regenerate after fire (e.g., young Pinus halepensis and P. pinaster forests); (iii) creation of a landscape mosaic of forest types including species with reduced flammability, (iv) infrastructure planning for direct fire attack in relation to the specific behavior for each fuel model [95]; and (v) implementation of policies to limit the abandonment of burned areas and actions to prevent the spread of invasive species in burned areas.

Forest protection measures should be integrated in the landscape level forest planning to balance stand level management goals and risk mitigation. A reduced rotation length will lower the risk of financial losses in stands susceptible to windthrow, bark beetle attacks or other disturbances predominantly affecting later development stages [96]. Increasing tree species diversity distributes risks and is likely to mitigate large-scale damage in the case of extreme events, but alternative species usually produce less timber than the currently favored fast growing conifers.

Integrating risk into forest management decision making is facilitated by applying a risk management process comprising three major steps: (i) risk analysis or risk assessment; (ii) risk handling; and (iii) risk control. For the first step different kind of models are used [97]. Risk handling in forestry can be promoted by educational efforts, e.g., through training courses focusing on identification and prevention of risks and furthermore on mitigation of occurred damages [98]. The second step involves determining expected costs of the disturbance with and without control or adaptation measures. Adaptive disturbance management would benefit from improved fire, storm and pest risk simulation [99] and projections of the effectiveness of alternative management options to reduce disturbance calamities. Furthermore, as the existing coping strategies may not be sufficient under climate change, new insurance concepts should be developed to distribute risks [100]. 
The preparedness to respond to increased pest and disease risks on the European level is only moderate; there are only a few ongoing measures recorded in the ECHOES database. In UK, the incidence of the Red band needle blight (Dothistroma septosporum) has increased dramatically particularly on Corsican pine (Pinus nigra ssp. laricio), and due to the extent and severity of the disease on this species, a temporary planting moratorium has been set on the Forestry Commission estate [101]. Despite the high demand for monitoring of pest species and diseases, Croatia, Hungary, Italy and Serbia are the only countries in the ECHOES database reporting monitoring of new and existing pest species and diseases as an ongoing adaptation measure. In addition, integrated control schemes for biotic risk agents are explored in selected forests in Austria. Shorter rotation length is used to reduce the risk of storm damage in several countries. In Germany, storm damage models and site mapping are applied to improve risk assessment. In France emergency plans for the handling of large-scale wind-blown wood have been developed in response to large recent damages. Design and promotion of fire-smart management at management unit/landscape level is an ongoing measure in the Mediterranean.

\subsubsection{Infrastructure and Transporting}

A dense forest road network is a prerequisite for the small-scale, structurally diverse thinning and harvesting practices recommended to adapt harvesting systems. Vital forest functions depend on such small-scale measures particularly in complex terrain such as mountain forests [102,103]. Access is furthermore a key element in coping with disturbance events (e.g., insect pest outbreaks, forest fires) as well as in proactive forest protection routines. Moreover, infrastructure supporting the mitigation of large-scale disturbance impacts should be expanded. Timber storage capacities — wet storage where the moisture level of timber is maintained at a high level by artificial irrigation, and foil storage where timber is stored by wrapping it in foil — could be expanded in order to muster both the phytosanitary necessity of an immediate salvage as well as a buffered release of timber into the timber market to prevent price volatility [104]. Forest road maintenance needs to be adapted to increasing peak precipitation and runoff [15] and shorter periods of frozen ground during the winter as well as thawing permafrost require changes in management schedules and/or machinery to respond to reduced accessibility to forest stands in the Boreal zone [105].

Forest infrastructure can also directly affect forest susceptibility to climate change. To adapt to increasingly dry conditions Cuculeanu et al. [106] proposed an augmentation of storage lakes and irrigation canals in Romania. Such measures might, however, only be feasible for highly valuable crop species and where irrigation is not in conflict with other land uses. Zebisch et al. [98] suggest for Germany that infrastructure measures should prevent a decreasing ground water table (e.g., via deactivating drainage systems) and that the natural water regime in floodplain forests should be restored.

So far, only few adaptation measures have been taken to adapt infrastructure and transport to climate change; only Finland, Cyprus, Croatia and Spain have reported ongoing adaptation measures in this category of the ECHOES database. In Finland, the proportion of high-capacity transportation by railroads has increased and a reduced impact harvesting technology has developed to better protect wet soils. As water availability is perceived as one of the most important factors in relation to oak decline in Croatia, a network of stations for the monitoring of groundwater levels was installed across the 
distribution range of lowland and floodplain forests of Pedunculate oak. This measure aims at collecting a sufficient amount of data on groundwater level dynamics to provide the basis for more in-depth understanding of the oak decline process. Furthermore, in Cyprus, Spain and Croatia infrastructure is improved for fire detection, control and suppression to meet increasing fire risks under climate change.

\subsection{Adaptation Options at the Policy Level}

A robust monitoring system is important to assess climate change impacts (including dieback and pest dynamics) and the reaction of forest ecosystems to the adaptive management strategies [107]. Reducing forest fragmentation through afforestation and by establishing connecting corridors between densely forested regions contributes to increasing biodiversity and thus enhances natural adaptive capacity $[8,23,108]$. Establishing forest management associations can help to improve management of fragmented forests with multiple owners, allowing suitable adaptation measures to be implemented. In general human capital is of paramount importance in climate change adaptation, and is a prerequisite to local implementation of adaptation measures. The capacity of forest owners to adapt to climate change in a planned way is strongly dependent on the individual's strength of belief in climate change and in the adaption measures [109]. Thus raising awareness of forest owners and practitioners about the impacts of climate change is important.

Adaptive measures often lead to higher costs and thus may weaken the economic situation of the enterprises [97]. However, measures that aim to increase adaptive capacity are likely to pay off through reducing the need for further planned adaptation. Investing in infrastructure, research and increasing awareness for adaptation measures are strategies which help to improve the socio-economic adaptive capacity [8].

At the policy level, adaptation to climate change may require adjustments in social, economic and political systems. Obstacles to be addressed include institutional and policy barriers, as current guidelines (e.g., for plant production in nurseries) are often designed for a stable climate regime [17]. Existing policy instruments need to be adapted or used for adaptation. For example, the Common Agricultural Policy (CAP) of the European Commission allows support for adaptation measures in forest management, but not all Member States use this mechanism [110]. Since policies in other sectors may influence decisions affecting forestry, inter-sectoral coordination is needed to ensure that policy development in related policy sectors are not contradictory or counterproductive in the context of forest management.

In the ECHOES database, high level adaptation options in risk management and policy forms the largest and most variable group of measures. In temperate regions, dissemination of knowledge related to climate change impacts is widely promoted; there are ongoing measures concerning dissemination of forecasts/scenarios of regional effects of climate change (Hungary), development and dissemination of improved forestry guidelines (Germany, France and Netherlands), creating a specific website for presentation and monitoring of national work plans to cope with climate change (Hungary) and conferences and workshops about adaptation measures to climate change for forest owners and stakeholders (Switzerland, Germany and Slovakia). Monitoring of climate change impacts has already started in Cyprus and in France where existing monitoring networks were adapted. Methods utilizing a range of remote sensing techniques are developed to monitor climate change impacts in Switzerland. 
Research is another important focus of ongoing measures. The database lists research on climate change related management guidelines (Slovakia), provenance trials to identify best adapted provenances under changing climate in Spain, and research on pest and diseases and new regeneration techniques for continuous-cover silviculture (Hungary). Increased mortality, in particular of Picea abies caused by Ips typographus has lead to search for species or varieties better adapted to new environments based on phenotypic and molecular characterization (Hungary, Switzerland, UK).

Forest owners are encouraged with incentives to apply adaptive forest management to forests with protective functions (Italy) and to convert highly vulnerable spruce or pine dominated forests into mixed forests (Germany). In Germany work qualification of private forest owners is supported. Investments in fire prevention policies (e.g., increasing private and public awareness, education campaigns of forest managers, etc.) are an important part of the adaptation to climate change addition in the Mediterranean parts of Europe. In the temperate continental and the Mediterranean region forest reserves for threatened forest species and networks of protected forests are established.

\section{Overview of Reported Adaptation Measures in Different European Regions}

The ECHOES database of climate change adaptation measures gives insights on the preparedness to climate change in different bioclimatic regions in Europe. The ECHOES data indicate that adaptation is ongoing all over Europe. The highest number of measures is reported for the Temperate Oceanic region, but when corrected for the number of respondent countries, the measures are equally distributed over all regions (Table 1).

When all measures are taken into account regardless of their status, adaptation measures dealing with high level adaptation options in risk management are the most common in all regions except the Boreal region, where a lot of regeneration, tending, thinning and management planning measures are reported (Figure 1). A closer look at the status of the measures reveals that in all regions forests are already managed to be more tolerant to future conditions and extreme events; i.e., species and provenances that are more tolerant to future conditions are used in regeneration, and tree species diversity is taken into account in both the regeneration and thinning and tending phase to enhance the adaptive capacity of forests. In Mediterranean region investments in fire prevention policies (e.g., increasing private and public awareness, education campaigns of forest managers) and improving infrastructure for fire detection, control and suppression have been initiated. However, there are also many country-specific measures which are still in the planning phase-e.g., although there is a growing theoretical awareness about reducing the biotic and abiotic damage, there is still a high developmental need for monitoring and early warning systems. The future challenge especially lies in a cross-border implementation of such systems and the coordinated operation of adequate instruments at the EU-level. 
Figure 1. Type of measures applied in different bioclimatic regions based on ECHOES data.

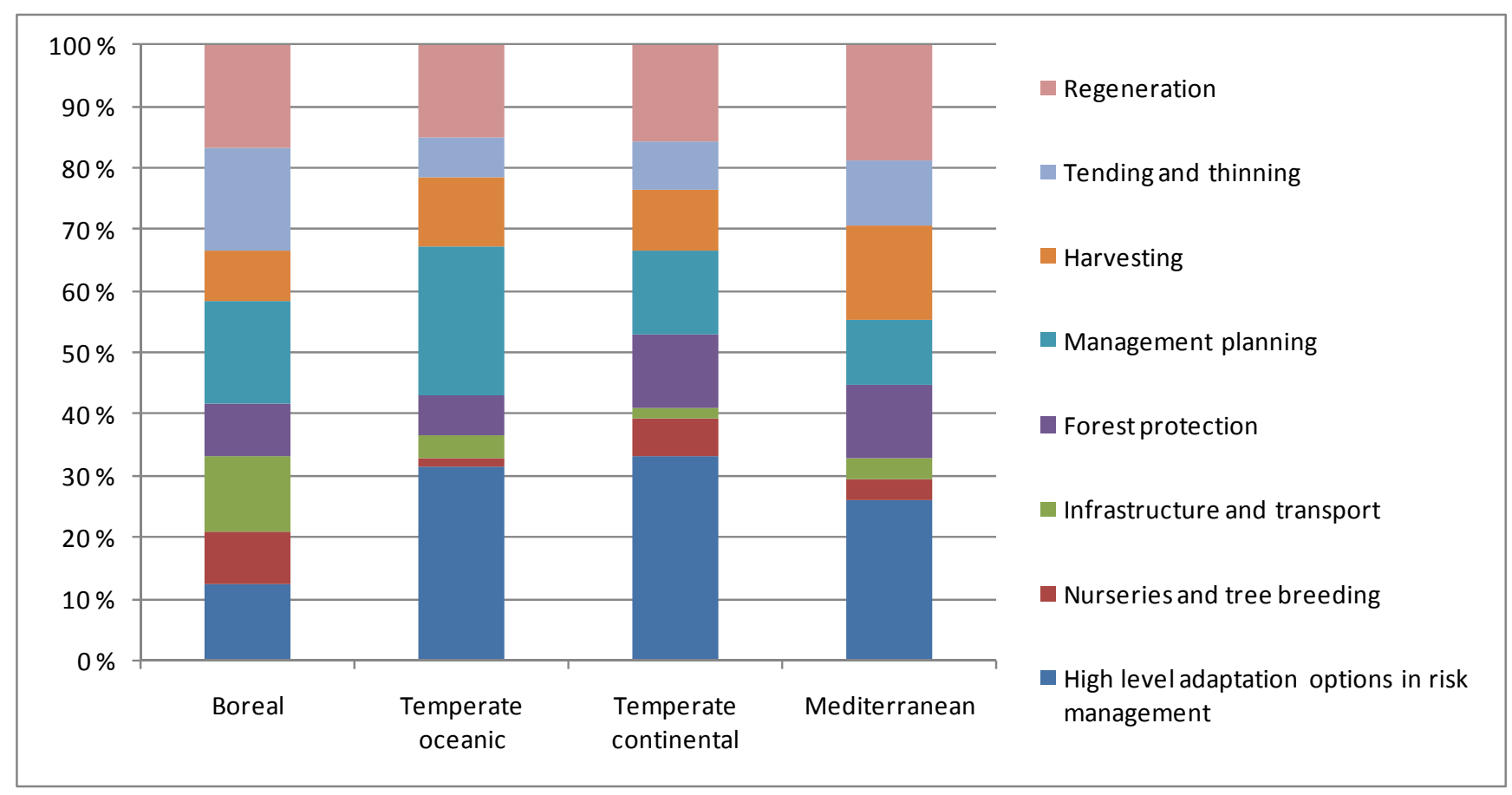

\section{Discussion and Conclusions}

There is a multitude of optional measures that can be used to adapt forest management to climate change. Some of these measures are not new and have already been used in forest management before climate change became an issue. Close-to-nature forestry, for example, was previously advocated to improve forest stability especially in monocultures of spruce and pine (e.g., [111]). Nowadays, the management approach is advocated also as a measure to increase adaptive capacity of stands to a changing climate [112]. It can be argued whether such measures should really be termed adaptive forest management strategies in the context of climate change. We considered also traditional measures in our review, because climate change aggravates many existing challenges, and measures that proved successful before may continue to be suitable in responding to increasing pressures under climate change. This should be kept in mind also when interpreting the state of implementation of adaptive management measures reported here, as it is obviously challenging to identify and implement novel response strategies where no analogue problems raised by climate change exist. An important question is how to select suitable measures from the multitude of options. As in traditional forest management, site conditions are important factors and the existing forest and management structures further narrow down the choice of feasible alternative measures. To consider adaptation to climate change in forest management, the forest manager needs to analyze exposure to climate change, assess potential impacts, and evaluate the adaptive capacity of both the forest ecosystem and the management system. Based on such circumspect analyses, measures that reduce vulnerability, either by reducing impacts of climate change or by improving adaptive capacity, can be identified [58].

Another important issue is which measures can be jointly applied, and whether trade-offs between measures exist that would prevent their combination at the stand level. Trade-offs between management objectives play a crucial role in multi-purpose SFM $[20,113,114]$ and some of the proposed adaptation 
measures may change the balance between current objectives and stakeholder interests. As already discussed in the review of higher level adaptation options, it is crucial to consider that different measures can be implemented at the stand and at the management unit or landscape scale.

Adaptation to climate change will have both direct and indirect costs-e.g., monitoring of biotic risk agents or improving infrastructure for better fire management will mean higher costs. Many adaptation measures like favoring drought resistant species or increasing tree species diversity will also decrease the capacity for timber production and thus reduce the future incomes from forestry. However, possible forest dieback and large-scale damage following the "no-action" option would likely have more severe economic impact. Furthermore, since adaptation and mitigation are intrinsically linked, adaptation in forest management is essential to ensure the continuation of the mitigation effect that forests have.

Improving the resilience of forests to future climate and supporting the adaptation of forestry practices should have top priority in forest policy development. A lot of knowledge and potential measures have already been identified in the literature, but practical implementation lags behind in many cases. Measures at the forest management level have been already implemented in many countries, but several important higher level measures, e.g., monitoring of new and existing pests and diseases to prevent large-scale disturbances, are still in the planning phase and a coordinated operation of adequate instruments at the EU-level is needed.

For adaptation to be successful it is of the utmost importance to disseminate the knowledge of suitable adaptation measures to decision makers at different levels, policy makers and affected stakeholder groups. Also, as the capacity to adapt to climate change in a planned way is strongly dependent on the individual's strength of belief in climate change [109], investments have to be made in the training of forest owners and forest workers, who need to implement the measures on the ground. The analysis of the ECHOES database demonstrates that this challenge is recognized in many European countries.

There are still several important research needs, e.g., resolving uncertainties about the full extent of climate change impacts, improving regional climate change projections, improving our understanding of tree responses, quantifying the adaptive capacity of the forest sector, and assessing the suitability of adaptation measures. However, tackling these research needs will not result in standardized, one-size-fits-all recommendations on how to best adapt forest management under a changing climate. Rather, local solutions, combining experience from available adaptation measures with advanced understanding from fundamental research, are a key to successfully adapting forest management to the challenges of climate change.

\section{Acknowledgments}

This paper is partly based on the study to the European Commission Directorate-General for Agriculture and Rural Development (AGRI-2007-G4-06) and was further developed under the project MOTIVE (number 226544, call FP7-ENV-2008-1) and the COST Action FP0703 ECHOES. We thank Tim Green for language revision and the ECHOES country respondents for their contributions to the database of adaptation measures. 


\section{Conflict of Interest}

The authors declare no conflict of interest.

\section{References}

1. Canadell, J.G.; Raupach, M.R. Managing forests for climate change mitigation. Science 2008, 320, 1456-1457.

2. Streck, C.; Scholz, S.M. The role of forests in global climate change: Whence we come and where we go. Int. Aff. 2006, 82, 861-879.

3. Climate Change 2007: The Physical Science Basis. Contribution of Working Group I to the Fourth Assessment Report of the Intergovernmental Panel on Climate Change; Solomon, S., Qin, D., Manning, M., Chen, Z., Marquis, M., Averyt, K.B., Tignor, M., Miller, H.L., Eds.; Cambridge University Press: Cambridge, UK; New York, NY, USA, 2007.

4. Solomon, S.; Plattner, G.K.; Knutti, R.; Friedlingstein, P. Irriversible climate change due to carbon dioxide emission. Proc. Natl. Acad. Sci. USA 2009, 106, 1704-1709.

5. Commission of the European Communities. Adapting to Climate Change in Europe-Options for EU Action. Green Paper from the Comission to the Council, the European Parliament, the European Economic and Social Committee and the Committee of the Regions; Commission of the European Communities: Brussels, Belgium, 2007.

6. Stern, N. The Economics of Climate Change: The Stern Review; Cambridge University Press: Cambridge, UK, 2007.

7. Seppälä, R.; Buck, A.; Katila, P. Adaptation of Forests and People to Climate Change; International Union of Forest Research Organizations (IUFRO): Helsinki, Finland, 2009.

8. Lindner, M.; Maroschek, M.; Netherer, S.; Kremer, A.; Barbati, A.; Garcia-Gonzalo, J.; Seidl, R.; Delzon, S.; Corona, P.; Kolström, M.; Lexer, M.J.; Marchetti, M. Climate change impacts, adaptive capacity, and vulnerability of European forest ecosystems. For. Ecol. Manag. 2010, 259, 698-709.

9. Adger, W.N.; Agrawala, S.; Mirza, M.M.Q.; Conde, C.; O’Brien, K.; Pulhin, J.; Pulwarty, R.; Smit, B.; Takahashi, K. Assessment of adaptation practices, options, constraints and capacity. In Climate Change 2007: Impacts, Adaptation and Vulnerability. Contribution of Working Group II to the Fourth Assessment Report of the Intergovernmental Panel on Climate Change; Parry, M.L., Canziani, O.F., Palutikof, J.P., van der Linden, P.J., Hanson, C.E., Eds.; Cambridge University Press: Cambridge, UK, 2007; pp. 717-743.

10. Parry, J.-E.; Hammill, A.; Drexhage, J. Climate Change and Adaptation; International Institute for Sustainable Development: Winnipeg, MB, Canada, 2005; p. 28.

11. Lenton, T.M.; Held, H.; Kriegler, E.; Hall, J.W.; Lucht, W.; Rahmstorf, S.; Schellnhuber, H.J. Tipping elements in the Earth's climate system. Proc. Natl. Acad. Sci. USA 2008, 105, 1786-1793.

12. Allen, C.D.; Macalady, A.K.; Chenchouni, H.; Bachelet, D.; McDowell, N.; Vennetier, M.; Kitzberger, T.; Rigling, A.; Breshears, D.D.; Hogg, E.H.; et al. A global overview of drought and heat-induced tree mortality reveals emerging climate change risks for forests. For. Ecol. Manag. 2010, 259, 660-684. 
13. Bigler, C.; Bräker, O.U.; Bugmann, H.; Dobbertin, M.; Rigling, A. Drought as an inciting mortality factor in scots pine stands of the Valais, Switzerland. Ecosystems 2006, 9, 330-343.

14. Seidl, R.; Schelhaas, M.J.; Lexer, M.J. Unraveling the drivers of intensifying forest disturbance regimes in Europe. Glob. Chang. Biol. 2011, 17, 2842-2852.

15. Spittlehouse, D.L.; Stewart, R.B. Adaptation to climate change in forest management. BC $J$. Ecosyst. Manag. 2003, 4, 1-11.

16. Ohlson, D.W.; McKinnon, G.A.; Hirsch, K.G. A structured decision-making approach to climate change adaptation in the forest sector. For. Chron. 2005, 81, 97-103.

17. Spittlehouse, D.L. Integrating climate change adaptation into forest management. For. Chron. 2005, 81, 691-695.

18. Ogden, A.E.; Innes, J. Incorporating climate change adaptation considerations into forest management planning in the boreal forest. Int. For. Rev. 2007, 9, 713-733.

19. Ogden, A.E.; Innes, J.L. Application of structured decision making to an assessment of climate change vulnerabilities and adaptation options for sustainable forest management. Ecol. Soc. 2009, 14, 1-11.

20. Fürstenau, C.; Badeck, F.W.; Lasch, P.; Lexer, M.J.; Lindner, M.; Mohr, P.; Suckow, F. Multiple-use forest management in consideration of climate change and the interests of stakeholder groups. Eur. J. For. Res. 2007, 126, 225-239.

21. Garcia-Gonzalo, J.; Jäger, D.; Lexer, M.J.; Peltola, H.; Briceño-Elizondo, E.; Kellomäki, S. Does climate change affect optimal planning solutions for multi-objective forest management? Allg. Forst Jagdztg 2008, 179, 78-95.

22. Seidl, R.; Rammer, W.; Jäger, D.; Lexer, M.J. Impact of bark beetle (Ips typographus L.) disturbance on timber production and carbon sequestration in different management strategies under climate change. For. Ecol. Manag. 2008, 256, 209-220.

23. Spiecker, H. Silvicultural management in maintaining biodiversity and resistance of forests in Europe-Temperate zone. J. Environ. Manag. 2003, 67, 55-65.

24. Lindner, M. How to adapt forest management in response to the challenges of climate change? In Climate Change and Forest Genetic Diversity: Implications for Sustainable Forest Management in Europe; Koskela, J., Buck, A., Tessier du Cros, E., Eds.; Bioversity International: Rome, Italy, 2007; pp. 31-42.

25. Bolte, A.; Ammer, C.; Löf, M.; Madsen, P.; Nabuurs, G.J.; Schall, P.; Spathelf, P.; Rock, J. Adaptive forest management in central Europe: Climate change impacts, strategies and integrative concept. Scand. J. For. Res. 2009, 24, 473-482.

26. Seidl, R.; Rammer, W.; Lexer, M.J. Climate change vulnerability of sustainable forest management in the Eastern Alps. Clim. Chang. 2011, 106, 225-254.

27. Commission of the European Communities. Communication from the Commission to the Council and the European Parliament on an EU Forest Action Plan; COM (2006) 302; Commission of the European Communities: Brussels, Belgium, 2006; pp. 1-13.

28. Rivas-Martínez, S.; Penas, A.; Díaz, T.E. Bioclimatic Map of Europe, Bioclimates; Cartographic Service, University of León: León, Spain, 2004.

29. SciVerse Scopus; Elsevier: Amsterdam, The Netherland, June 2008. Available online: www.scopus.com (accessed on 10 October 2011). 
30. Badeck, F.-W.; Furstenau, C.; Lasch, P.; Suckow, F.; Peltola, H.; Garcia-Gonzalo, J.; Briceño-Elizondo, E.; Kellomäki, S.; Lexer, M.J.; Jäger, D.; et al. Adaptive Forest Management at the Scale of Management Units; Research Notes; Faculty of Forestry, University of Joensuu: Joensuu, Finland, 2005; pp. 315-382.

31. Broadmeadow, M.S.J.; Ray, D.; Samuel, C.J.A. Climate change and the future for broadleaved tree species in Britain. Forestry 2005, 78, 145-161.

32. Resco de Dios, V.; Fischer, C.; Colinas, C. Climate change effects on Mediterranean forests and preventive measures. New For. 2007, 33, 29-40.

33. Czajkowski, T.; Bolte, A. Unterschiedliche Reaktion deutscher und polnischer Herkünfte der Buche (Fagus sylvatica L.) auf Trockenheit. Allg. Forst Jagdztg 2005, 177, 30-40.

34. Ehleringer, J.R.; Monson, R.K. Evolutionary and ecological aspects of photosynthetic pathway variation. Annu. Rev. Ecol. Syst. 1993, 24, 411-439.

35. Vitasse, Y.; Delzon, S.; Bresson, C.C.; Michalet, R.; Kremer, A. Altitudinal differentiation in growth and phenology among populations of temperate-zone tree species growing in a common garden. Can. J. For. Res. 2009, 39, 1259-1269.

36. Kremer, A. Evolutionary responses of European oaks to climate change. Ir. For. 2010, 67, 53-65.

37. Wang, T.; Hamann, A.; Yanchuk, A.; O’Neill, G.A.; Aitken, S.N. Use of response functions in selecting lodgepole pine populations for future climates. Glob. Chang. Biol. 2006, 12, 2404-2416.

38. O'Neill, G.A.; Hamann, A.; Wang, T. Accounting for population variation improves estimates of the impact of climate change on species' growth and distribution. J. Appl. Ecol. 2008, 45, 1040-1049.

39. Reich, P.B.; Oleksyn, J. Climate warming will reduce growth and survival of Scots pine except in the far north. Ecol. Lett. 2008, 11, 588-597.

40. Teissier du Cros, E. Un ensemble cohérent de références pour la gestion et la conservation des ressources génétiques forestières en France. Rev. For. Fr. 2000, 52, 391-400.

41. Fenning, T.M.; Walter, C.; Gartland, K.M.A. Forest Biotech and climate change. Nat. Biotechnol. 2008, 26, 615-617.

42. Nelson, C.D.; Johnsen, K.H. Genomic and physiological approaches for advancing forest tree improvement. Tree Physiol. 2008, 28, 1135-1143.

43. Scotti-Saintagne, C.; Bodénès, C.; Barreneche, T.; Bertocchi, E.; Plomion, C.; Kremer, A. Detection of quantitative trait loci controlling bud burst and height growth in Quercus robur L. Theor. Appl. Genet. 2004, 109, 1648-1659.

44. Casasoli, M.; Derory, J.; Morera-Dutrey, C.; Brendel, O.; Porth, I.; Guehl, J.M.; Villani, F.; Kremer, A. Comparison of QTLs for adaptive traits between oak and chestnut based on an EST consensus map. Genetics 2006, 172, 533-546.

45. Yakovlev, I.A.; Fossdal, C.; Johnsen, Ø.; Junttila, O.; Skrøppa, T. Analysis of gene expression during bud burst initiation in Norway spruce via ESTs from subtracted cDNA libraries. Tree Genet. Genomes 2006, 2, 39-52.

46. Yakovlev, I.A.; Asante, D.K.A.; Fossdal, C.G.; Partanen, J.; Junttila, O.; Johnsen, O. Dehydrins expression related to timing of bud burst in Norway spruce. Planta 2008, 228, 459-472. 
47. Frewen, B.E.; Chen, T.H.H.; Howe, G.T.; Davis, J.; Rohde, A.; Boerjan, W.; Bradshaw, H.D. Quantitative trait loci and candidate gene mapping of bud set and bud flush in Populus. Genetics 2000, 154, 837-845.

48. Hurme, P.; Repo, T.; Savolainen, O.; Pääkkönen, T. Genetic basis of climatic adaptation in Scots pine by Bayesian quantitative trait locus analysis. Genetics 2000, 155, 1309-1326.

49. Lauteri, M.; Scartazza, A.; Guido, M.C.; Brugnoli, E. Genetic variation in photo synthetic capacity, carbon isotope discrimination and mesophyll conductance in provenances of Castanea sativa adapted to different environments. Funct. Ecol. 1997, 11, 675-683.

50. Brendel, O.; le ThieC, D.; Saintagne, C.; Bodénès, C.; Kremer, A.; Guehl, J.M. Detection of quantitative trait loci controlling water use efficiency and related traits in Quercus robur L. Tree Genet. Genomes 2008, 4, 263-278.

51. Lamy, J.-B.; Bouffier, L.; Burlett, R.; Plomion, C.; Cochard, H.; Delzon, S. Uniform selection as a primary force reducing population genetic differentiation of cavitation resistance across a species range. PloS One 2011, 6, e23476:1-e23476:12.

52. Kowalski, T.; Holdenrieder, O. Pathogenicity of Chalara fraxinea. For. Pathol. 2009, 39, 1-7.

53. Czajkowski, T.; Kühling, M.; Bolte, A. Impact of the 2003 summer drought on growth of beech sapling natural regeneration (Fagus sylvatica L.) in north-eastern Central Europe. Allg. Forst Jagdztg 2005, 176, 133-143.

54. Lloret, F.; Peñuelas, J.; Ogaya, R. Establishment of co-existing Mediterranean tree species under a varying soil moisture regime. J. Veg. Sci. 2004, 15, 237-244.

55. Luis, V.C.; Puértolas, J.; Climent, J.; Peters, J.; González-Rodríguez, M.A.; Morales, D.; Jiménez, M.S. Nursery fertilization enhances survival and physiological status in Canary Island pine (Pinus canariensis) seedlings planted in a semiarid environment. Eur. J. For. Res. 2009, 128, 221-229.

56. Del Campo, A.D.; Navarro, R.M.; Hermoso, J.; Ibáñez, J. Relationships between site and stock quality in Pinus halepensis Mill. reforestation of semiarid landscapes in Eastern Spain. Ann. For. Sci. 2007, 64, 719-731.

57. Bravo, F.; Bravo-Oviedo, A.; Ruiz, R.; Montero, G. Selvicultura y Cambio Climático. In Compendio de Selvicultura APlicada en España; Serrada, R., Montero, G., Reque, J., Eds.; FUCOVASA: Madrid, Spain, 2008; p. 1178.

58. Seidl, R.; Rammer, W.; Lexer, M.J. Adaptation options to reduce climate change vulnerability of sustainable forest management in the Austrian Alps. Can. J. For. Res. 2011, 41, 694-706.

59. Garcia-Gonzalo, J.; Peltola, H.; Briceño-Elizondo, E.; Kellomäki, S. Changed thinning regimes may increase carbon stock under climate change: A case study from a Finnish boreal forest. Clim. Chang. 2007, 81, 431-454.

60. Briceño-Elizondo, E.; Garcia-Gonzalo, J.; Peltola, H.; Matala, J.; Kellomäki, S. Sensitivity of growth of Scots pine, Norway spruce and silver birch to climate change and forest management in boreal conditions. For. Ecol. Manag. 2006, 232, 152-167.

61. Sabaté, S.; Gracia, C.A.; Sánchez, A. Likely effects of climate change on growth of Quercus ilex, Pinus halepensis, Pinus pinaster, Pinus sylvestris and Fagus sylvatica forests in the Mediterranean region. For. Ecol. Manag. 2002, 162, 23-37. 
62. Köhler, M.; Sohn, J.; Nägele, G.; Bauhus, J. Can drought tolerance of Norway spruce (Picea abies (L.) Karst.) be increased through thinning? Eur. J. For. Res. 2010, 129, 1109-1118.

63. Wilson, J.S.; Oliver, C.D. Stability and density management in Douglas-fir plantations. Can. J. For. Res. 2000, 30, 910-920.

64. Slodicak, M.; Novak, J. Silvicultural measures to increase the mechanical stability of pure secondary Norway spruce stands before conversion. For. Ecol. Manag. 2006, 224, 252-257.

65. Schelhaas, M.J. The wind stability of different silvicultural systems for Douglas-fir in the Netherlands: A model-based approach. Forestry 2008, 81, 399-414.

66. Gardiner, B.A.; Stagey, G.R.; Belcher, R.E.; Wood, C.J. Field and wind tunnel assessments of the implications of respacing and thinning for tree stability. Forestry 1997, 70, 233-252.

67. Jactel, H.; Nicoll, B.C.; Branco, M.; Gonzalez-Olabarria, J.R.; Grodzki, W.; Långström, B.; Moreira, F.; Netherer, S.; Orazio, C.; Piou, D.; Santos, H.; Schelhaas, M.J.; Tojic, K.; Vodde, F. The influences of forest stand management on biotic and abiotic risks of damage. Ann. For. Sci. 2009, 66, 1-18.

68. Felton, A.; Lindbladh, M.; Brunet, J.; Fritz, Ö. Replacing coniferous monocultures with mixed-species production stands: An assessment of the potential benefits for forest biodiversity in northern Europe. For. Ecol. Manag. 2010, 260, 939-947.

69. Niinemets, Ü.; Valladares, F. Tolerance to shade, drought, and waterlogging of temperate northern hemisphere trees and shrubs. Ecol. Monogr. 2006, 76, 521-547.

70. Ciancio, O.; Iovino, F.; Menguzzato, G.; Nicolaci, A.; Nocentini, S. Structure and growth of a small group selection forest of calabrian pine in Southern Italy: A hypothesis for continuous cover forestry based on traditional silviculture. For. Ecol. Manag. 2006, 224, 229-234.

71. Pommerening, A.; Murphy, S.T. A review of the history, definitions and methods of continuous cover forestry with special attention to afforestation and restocking. Forestry 2004, 77, 27-44.

72. Gardiner, B.A.; Quine, C.P. Management of forests to reduce the risk of abiotic damage-A review with particular reference to the effects of strong winds. For. Ecol. Manag. 2000, 135, 261-277.

73. Peltola, H.; Kellomäki, S.; Väisänen, H.; Ikonen, V.P. A mechanistic model for assessing the risk of wind and snow damage to single trees and stands of Scots pine, Norway spruce, and birch. Can. J. For. Res. 1999, 29, 647-661.

74. Kellomäki, S.; Maajärvi, M.; Strandman, H.; Kilpeläinen, A.; Peltola, H. Model computations on the climate change effects on snow cover, soil moisture and soil frost in the boreal conditions over Finland. Silva Fenn. 2010, 44, 213-233.

75. Cyprus Forestry Department. Short Term Action Plan Against Drought Impacts in State Forests; Forestry Department: Lefkosia, Cyprus, 2009.

76. Böttcher, H.; Lindner, M. Managing forest plantations for carbon sequestration today and in the future. In Ecosystem Goods and Services from Plantation Forests; Bauhus, J., van der Meer, P., Kanninen, M., Eds.; Earthscan: London, UK, 2010.

77. Lindner, M. Developing adaptive forest management strategies to cope with climate change. Tree Physiol. 2000, 20, 299-307.

78. Bodin, P.; Wiman, B.L.B. The usefulness of stability concepts in forest management when coping with increasing climate uncertainties. For. Ecol. Manag. 2007, 242, 541-552. 
79. Ciancio, O.; Nocentini, S. Biodiversity conservation and systemic silviculture: Concepts and applications. Plant Biosyst. 2011, 145, 411-418.

80. Corona, P.; Scotti, R. Systemic silviculture, adaptive management and forest monitoring perspectives. Ital. J. For. Mt. Environ. 2011, 66, 219-224.

81. Barbati, A.; Corona, P.; Iovino, F.; Marchetti, M.; Menguzzato, G.; Portoghesi, L. The application of the ecosystem approach through sustainable forest management: An Italian case study. Ital. J. For. Mt. Environ. 2010, 65, 1-17.

82. Wolfslehner, B.; Seidl, R. Harnessing ecosystem models and multi-criteria decision analysis for the support of forest management. Environ. Manag. 2010, 46, 850-861.

83. Millar, C.I.; Stephenson, N.L.; Stephens, S.L. Climate change and forests of the future: Managing in the face of uncertainty. Ecol. Appl. 2007, 17, 2145-2151.

84. Ascough, J.C.; Maier, H.R.; Ravalico, J.K.; Strudley, M.W. Future research challenges for incorporation of uncertainty in environmental and ecological decision-making. Ecol. Model. 2008, 219, 383-399.

85. Rouault, G.; Candau, J.N.; Lieutier, F.; Nageleisen, L.M.; Martin, J.C.; Warzée, N. Effects of drought and heat on forest insect populations in relation to the 2003 drought in Western Europe. Ann. For. Sci. 2006, 63, 613-624.

86. Desprez-Loustau, M.; Robin, C.; Reynaud, G.; Déqué, M.; Badeau, V.; Piou, D.; Husson, C.; Marcais, B. Simulating the effects of a climate-change scenario on the geographical range and activity of forest-pathogenic fungi. Can. J. Plant Pathol. 2007, 29, 101-120.

87. Kozlov, M.V. Losses of birch foliage due to insect herbivory along geographical gradients in Europe: A climate-driven pattern? Clim. Chang. 2008, 87, 107-117.

88. Seidl, R.; Schelhaas, M.J.; Lexer, M.J. Unraveling the drivers of intensifying forest disturbance regimes in Europe. Glob. Chang. Biol. 2011, 17, 2842-2852.

89. Moore, B.A.; Allard, G.B. Climate change impacts on forest health. In Forest Health \& Biosecurity, Working Paper FBS/34E; FAO: Rome, Italy, 2008; p. 38.

90. Netherer, S.; Schopf, A. Potential effects of climate change on insect herbivores in European forests - General aspects and the pine processionary moth as specific example. For. Ecol. Manag. 2010, 259, 831-838.

91. Netherer, S.; Nopp-Mayr, U. Predisposition assessment systems (PAS) as supportive tools in forest management-Rating of site and stand-related hazards of bark beetle infestation in the High Tatra Mountains as an example for system application and verification. For. Ecol. Manag. 2005, 207, 99-107.

92. Baier, P.; Pennerstorfer, J.; Schopf, A. Phenips-A comprehensive phenology model of Ips typographus (L.) (Col. Scolytidae) as a tool for hazard rating of bark beetle infestation. For. Ecol. Manag. 2007, 249, 171-186.

93. Christensen, J.H.; Hewitson, B.; Busuioc, A.; Chen, A.; Gao, X.; Held, I.; Jones, R.; Kolli, R.K.; Kwon, W.-T.; Laprise, R.; et al. Regional climate projections. In Climate Change 2007: The Physical Science Basis. Contribution of Working Group I to the Fourth Assessment Report of the Intergovernmental Panel on Climate Change; Solomon, S., Qin, D., Manning, M., Chen, Z., Marquis, M., Averyt, K.B., Tignor, M., Miller, H.L., Eds.; Cambridge University Press: Cambridge, UK; New York, NY, USA, 2007. 
94. Moreno, J.M. Impacts on Natural Hazards of Climatic Origin, C. Forest fires risk; ECCE project final report; ECCE: Madrid, Spain, 2005; pp. 559-592.

95. Camia, A.; Barbosa, P.; Amatulli, G.; San Miguel Ayanz, J. Fire danger forecast in the European Forest Fire Information System (EFFIS). In Proceedings of the Wildfire2007 IV International Wildland Fire Conference, Seville, Spain, 13-17 May 2007.

96. Wermelinger, B. Ecology and management of the spruce bark beetle Ips typographus - A review of recent research. For. Ecol. Manage. 2004, 202, 67-82.

97. Hanewinkel, M.; Hummel, S.; Cullmann, D.A. Modelling and economic evaluation of forest biome shifts under climate change in Southwest Germany. For. Ecol. Manag. 2010, 259, 710-719.

98. Zebisch, M.; Grothmann, T.; Schröter, D.; Hasse, C.; Fritsch, U.; Cramer, W. Klimawandel in Deutschland, Vulnerabilität und Anpassungsstrategien klimasensitiver Systeme. Report of Potsdam-Institut für Klimafolgenforschung. Climate Change 2005, 8, 203.

99. Arca, B.; Duce, P.; Laconi, M.; Pellizzaro, G.; Salis, M.; Spano, D. Evaluation of FARSITE simulator in Mediterranean maquis. Int. J. Wildland Fire 2007, 16, 563-572.

100. Fuhrer, J.; Beniston, M.; Fischlin, A.; Frei, C.; Goyette, S.; Jasper, K.; Pfister, C. Climate risks and their impact on agriculture and forests in Switzerland. Clim. Chang. 2006, 79, 79-102.

101. Brown, A.; Webber, J. Red Band Needle Blight of Conifers in Britain; Forestry Commission: Edinburgh, UK, 2008.

102. Brang, P.; Schönenberger, W.; Frehner, M.; Schwitter, R.; Thormann, J.; Wasser, B. Management of protection forests in the European Alps: An overview. For. Snow Landsc. Res. 2006, 80, 23-44.

103. Woltjer, M.; Rammer, W.; Brauner, M.; Seidl, R.; Mohren, G.M.J.; Lexer, M.J. Coupling a 3D patch model and a rockfall module to assess rockfall protection in mountain forests. J. Environ. Manag. 2008, 87, 373-388.

104. Odenthal-Kahabka, J. Storm Handbook. Coping with Storm Damaged Timber; Forest Research Institute of Baden-Württemberg: Freiburg, Germany, 2005. Available online: http://www.waldwissen.net/waldwirtschaft/schaden/sturm_schnee_eis/fva_sturmhandbuch/index EN?redir=1 (accessed on 10 October 2011).

105. Keskitalo, E.C.H. Vulnerability and adaptive capacity in forestry in northern Europe: A Swedish case study. Clim. Chang. 2008, 87, 219-234.

106. Cuculeanu, V.; Tuinea, P.; Bâlteanu, D. Climate change impacts in Romania: Vulnerability and adaptation options. GeoJournal 2002, 57, 203-209.

107. Corona, P. Integration of forest mapping and inventory to support forest management. IForest 2010, 3, 59-64.

108. Honnay, O.; Verheyen, K.; Butaye, J.; Jacquemyn, H.; Bossuyt, B.; Hermy, M. Possible effects of habitat fragmentation and climate change on the range of forest plant species. Ecol. Lett. 2002, 5, 525-530.

109. Blennow, K.; Persson, J. Climate change: Motivation for taking measure to adapt. Glob. Environ. Chang. 2009, 19, 100-104.

110. Ellison, D. Addressing adaptation in the EU policy framework. In Developing Adaptation Policy and Practice in Europe: Multi-level Governance of Climate Change; Keskitalo, E.C., Ed.; Springer: Berlin, Germany, 2010; pp. 39-96. 
111. Klimo, E.; Kulhavý, J. Norway spruce monocultures and their transformation to close-to-nature forests from the point of view of soil changes in the Czech Republic. Ekol. Bratislava 2006, 25, 27-43.

112. Meyer, P. Network of strict forest reserves as reference system for close to nature forestry in Lower Saxony, Germany. For. Snow Landsc. Res. 2005, 79, 33-44.

113. Seidl, R.; Rammer, W.; Jäger, D.; Currie, W.S.; Lexer, M.J. Assessing trade-offs between carbon sequestration and timber production within a framework of multi-purpose forestry in Austria. For. Ecol. Manag. 2007, 248, 64-79.

114. Baskent, E.Z.; Keleş, S. Developing alternative forest management planning strategies incorporating timber, water and carbon values: An examination of their interactions. Environ. Model. Assess. 2009, 14, 467-480.

(C) 2011 by the authors; licensee MDPI, Basel, Switzerland. This article is an open access article distributed under the terms and conditions of the Creative Commons Attribution license (http://creativecommons.org/licenses/by/3.0/). 